\title{
Valuation Models for Holiday Rentals' Daily Rates: Price Composition Based on Booking.com
}

\author{
José António C. Santos ${ }^{1, * \mathbb{D}}$, Manuel A. Fernández-Gámez ${ }^{2}$, Miguel Ángel Solano-Sánchez ${ }^{3}$, \\ Francisco José Rey-Carmona ${ }^{3}$ and Lorena Caridad y López del Rio ${ }^{3}$ \\ 1 ESGHT (School of Management, Hospitality and Tourism) and CinTurs (Research Center for Tourism, \\ Sustainability and Well-being), Universidade do Algarve, 8139 Faro, Portugal \\ 2 Department of Finance and Accounting, University of Malaga, 29016 Malaga, Spain; mangel@uma.es \\ 3 Faculty of Law and Business and Economic Sciences, University of Cordoba, 14071 Cordoba, Spain; \\ miguelangsolano@gmail.com (M.Á.S.-S.); td1recaf@uco.es (F.J.R.-C.); d92calol@uco.es (L.C.yL.d.R.) \\ * Correspondence: jasantos@ualg.pt
}

check for

updates

Citation: Santos, J.A.C.; Fernández-Gámez, M.A.; Solano-Sánchez, M.Á.;

Rey-Carmona, F.J.; López del Rio, L.C.y. Valuation Models for Holiday Rentals' Daily Rates: Price Composition Based on Booking.com. Sustainability 2021, 13, 292. https://doi.org/10.3390/ su13010292

Received: 30 November 2020 Accepted: 28 December 2020 Published: 30 December 2020

Publisher's Note: MDPI stays neutral with regard to jurisdictional clai$\mathrm{ms}$ in published maps and institutional affiliations.

Copyright: (C) 2020 by the authors. Licensee MDPI, Basel, Switzerland. This article is an open access article distributed under the terms and conditions of the Creative Commons Attribution (CC BY) license (https:// creativecommons.org/licenses/by/ $4.0 /)$.

\begin{abstract}
In recent years, the number of sharing economy accommodations has grown exponentially due to the Internet and peer-to-peer networks, which has made researchers increasingly interested in analysing this new type of lodging. This study sought to develop models that determine the significant variables for the daily price of staying in holiday rentals based on data extracted from Booking.com and other sources. The hedonic pricing method (HPM) was selected to conduct the research as this methodology has been widely used in real estate valuation and hotel daily rate determination; however, the HPM is still rarely used for holiday rentals. The study focused on the city of Seville, where a notable increase in holiday rentals has been observed in recent years. Variables related to the accommodation typology, including location, size and equipment, as well as seasonality, are the most influential factors in the proposed models. These results are of interest to both owners and users of holiday rentals and can help these individuals to determine if the price of a stay is what would commonly be offered in the market under normal circumstances.
\end{abstract}

Keywords: holiday rental; daily rate pricing; sharing economy; hedonic pricing method; Booking.com

\section{Introduction}

The sharing economy's rise has proved to be a disruptive innovation in the tourist accommodation sector, primarily spreading through peer-to-peer (P2P) platforms such as Airbnb [1]. As opposed to conventional accommodations, these "holiday rentals" have emerged as part of the sharing economy and captured a considerable share of the accommodation market [2]. Although this new offer appears to pose a threat to the hotel sector [3], some studies have concluded that the two types of accommodation are not in direct competition [4].

According to Wegmann and Jiao [5], holiday rentals are private accommodations or part of private residences (i.e., rooms) that are available to tourists. This new form of accommodation is characterised mainly by the utilisation of unused housing not as conventional rental property for residential use but rather for tourism purposes. Recent phenomena such as the Internet have allowed P2P platforms to emerge and function as intermediaries [6], putting millions of suppliers and potential customers in direct contact around the world. On the other hand, online reviews and other forms of user-generated content on the Internet, also known as electronic word of mouth or e-WOM [7] have become determining factors for the decision-making process of booking accommodation [8-11]. This innovation has combined with holiday rentals' advantages over conventional accommodations, such as better value for money and tourists' search for local experiences [3,12], to make holiday rentals a global phenomenon. 
Worldwide, the expansion of P2P platforms has led to the growth of the holiday rental sector, which has been continually expanding and spreading around the globe. Regarding the sector's revenues, the statistics shown in Figure 1 confirm a pronounced growth of $10.1 \%$ from 2017 to 2018, with an estimated annual increase of $7.5 \%$ on average. Forecasts suggest that the sector will grow by 28.3\% overall from 2019 to 2023.

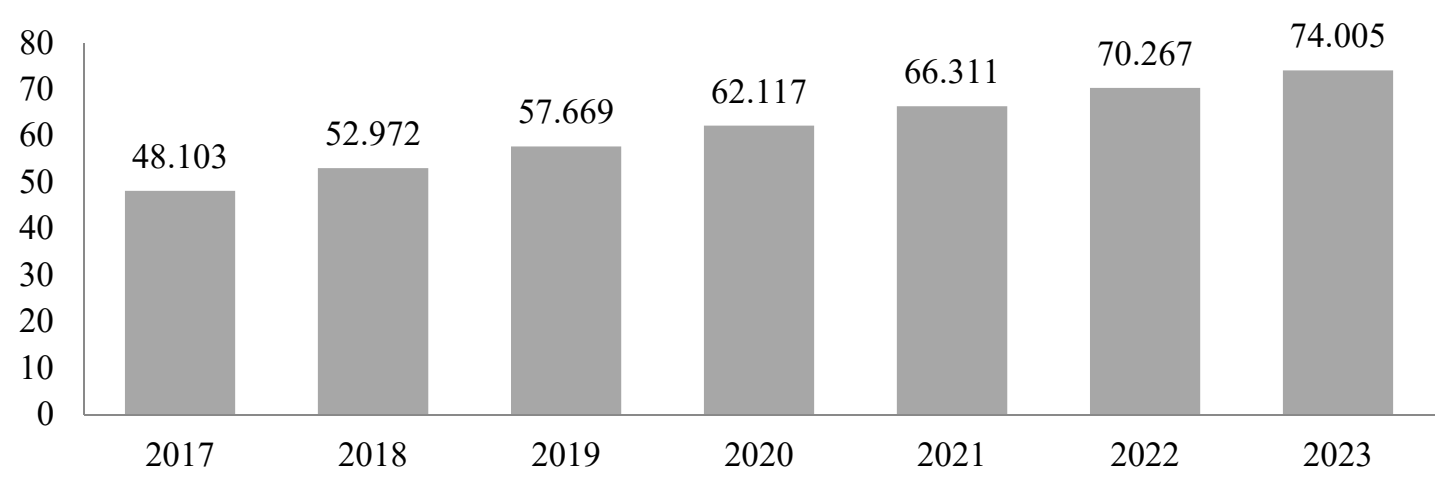

Figure 1. Revenue for holiday rentals worldwide in millions of United States (US) dollars. Note: Estimates start with 2019. Source: Statista [13].

Figure 2 reveals that a similar increase has been registered in the number of guests, with a growth of $5.9 \%$ from 2017 to 2018 . Analysts expect this number to rise by $21.5 \%$ overall from 2019 to 2023.

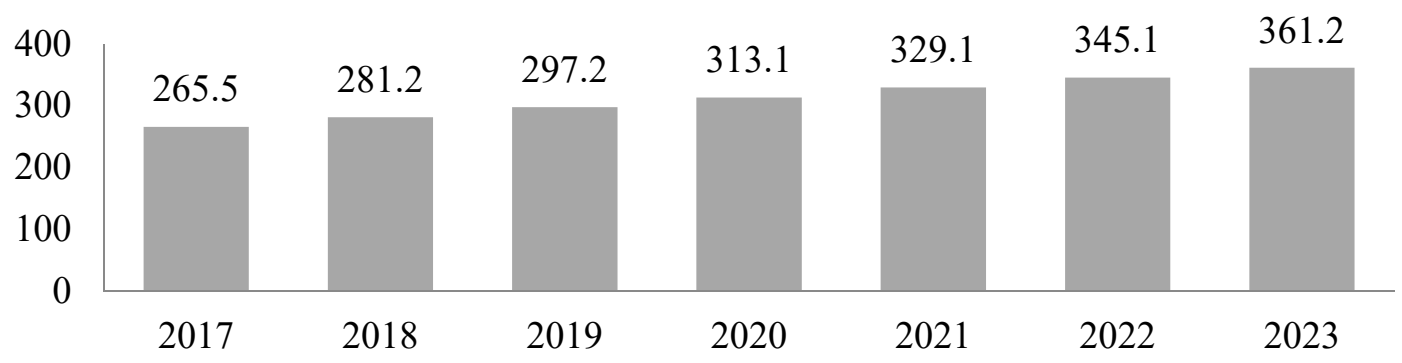

Figure 2. Millions of holiday rentals users. Note: Estimates start with 2019. Source: Statista [13].

This radical innovation's importance in the tourist accommodation sector underlines the need for an in-depth investigation of the determinants of valuation in holiday rentals' daily rates. This study thus sought to develop hedonic regression models that facilitate, through predetermined variables, estimations of daily prices of stays in holiday rentals. The research also had additional related objectives, such as testing how the variables included in the dataset affect the composition of holiday rentals' daily prices and excluding any irrelevant variables.

The hedonic pricing method (HPM) has been widely used in real estate valuation and the hotel sector [8]. However, studies applying this method to holiday rentals are still scarce, and these investigations have mainly used Airbnb and Tripadvisor as data sources. The present research relied on data extracted from Booking.com, which offers a more detailed description of accommodations regarding amenities, including the exact location and size in square meters $\left(\mathrm{m}^{2}\right)$. These last data are unavailable on Airbnb. The Booking.com selection as the main data source is consistent with the hypothesis that the two variables present in Booking.com tend to be the ones that offer the greatest explanatory power in this type of study.

The final proposed models comprised a broad set of variables concerning size, distance to the city centre, amenities, rating and seasonality; these same variables were present in studies of several types of accommodation (e.g., hotels and holiday rentals) that have 
adopted Airbnb and Tripadvisor as their data source. In addition, variables provided by Booking.com were included that had already been used in research on other accommodations but not on holiday rentals. The current models were operationalised in the context of a cultural tourism city destination with a large offer of holiday rentals; thus, the models can be reapplied to similar urban destinations, especially in Europe.

The remarkable increase in holiday rentals experienced worldwide has also occurred in Seville over the last two years, since legal registration has been required, making this city an ideal research context. Furthermore, Seville has recently been recognised as an important city destination. The prestigious Lonely Planet 2017 guide chose Seville as the best city to travel to in 2018, in the publication Best in Travel 2018. The World Travel and Tourism Council also announced Seville as the 2019 Global Summit host.

This paper is structured as follows. The above introduction presented an overview of the holiday rentals sector worldwide and in the city of Seville. Section 2 details the literature review, identifies the most important variables related to real estate and accommodation valuation, defines relevant concepts and examines approaches and methods that could be appropriate for this study. Section 3 discusses the characterisation of the research population and dataset and explains the methodology applied to choose and extract data on the selected variables. The results are presented and discussed in Section 4. Finally, Section 5 presents the conclusions and models' limitations and outlines the future research needed on this topic.

\section{Literature Review}

Most authors trace the origin of the HPM to Court's work [14]. This author was the first to use the term "hedonic" in a study that tried to determine probable increases in automobile prices. Later, Rosen [15] laid the theoretical foundations for HPM, defining it as a system that disaggregates the prices of heterogeneous goods or services to determine the sum of what each attribute or variable contributes to these prices. This researcher's model facilitated the estimation of goods or services' prices through previously fixed variables. This method became quite popular thereafter, and it was applied in many different contexts.

This literature review was carried out based on a triple perspective. First, the real estate dimension of the properties under study (i.e., holiday rentals) required an analysis of real estate valuation studies using the HPM and other similar methodologies. Second, the present review needed to examine HPM models in the existing literature that were developed to assess prices of tourist accommodation stays in order to find variables already tested that could be adapted for use in the current study. Abundant literature was found regarding valuation in terms of hotels' daily rates. Last, this literature review focused on methods used to price holiday rentals.

\subsection{Estimation of Real Estate Prices}

Ridker and Henning [16] can be considered pioneers in the application of the HPM to housing valuation, after which came studies such as Kang and Reichert [17] and Palmquist [18]. In later studies, Brañas-Garza and Caridad y Ocerin [19], Ceular-Villamandos and Caridad y Ocerin [20] and Muñoz Fernández [21] stand out, as well as similar research related to property valuation using other methodologies such as artificial neural networks in real estate [22] and business properties [23].

\subsection{Estimation of Hotels' Daily Rates}

The HPM has been used to determine hotels' daily rates in studies related to coastal tourism, such as those by Coenders, Espinet and Sáez [24] and Espinet, Sáez and Coenders [25]. Subsequently, Rigall i Torrent et al. [26] focused on the Mediterranean coast in general and on Catalonia in particular. In all these studies, similar variables appear as relevant, such as the moment in time when the price is fixed (i.e., seasonality), distance to the beach, the availability of a swimming pool, parking and other amenities and the accommodations' size in $\mathrm{m}^{2}$. 
Relevant research has been conducted regarding stays in hotels by Chen and Rothschild [27] on Taiwan, Andersson [28] on Singapore, and Zhang, Ye and Law [29] on New York City. Others focus on green, sustainable and "environmentally friendly" hotels, such as Kuminoff, Zhang and Rudi [30] on the state of Virginia in the US and SánchezOllero, García-Pozo, and Marchante-Mera [31] on Andalusia in Spain. All these studies emphasised variables related to the distance from accommodations to city centres, hotel category, television (TV) availability and pet admission, among others, presenting strong price conditionings for hotel room stays.

Soler-García and Gémar-Castillo [32] carried out especially significant work on the impact of Seville's April Fair on the prices of the city's hotels, demonstrating that special events in the city are a factor to consider. Along the same lines, Soler García and Gémar Castillo [33] combined hedonic methodology with geographically weighted regressions for Málaga in Spain, giving special importance to the distance to the city centre, train station or airport, using Google Maps as data source. Another study by Soler García, Gémar Castillo, Correia and Serra [34] focused on the determinants of hotel prices in the Algarve region in Portugal. These articles used data from TripAdvisor and variables such as hotels' number of stars and rooms, their distance from the city centre and reputational factors such as customer ratings or photos obtained on the Web.

Various studies have also been conducted on hotel price estimation using Booking.com as their main source of data. This is the case for Stojchevska, Naumoski and Mitreski [35], who focused especially on amenities such as the availability of a TV, terrace, balcony, bathtub or parking. Mondaca-Marino, Guala, Montecinos-Astorga and Salazar [36] and Nieto-García, Resce, Ishizaka, Occhiocupo and Viglia [37] similarly highlighted the accommodations' location. These studies present Booking.com listings as a prominent and globally known data source to consider.

\subsection{Estimation of Holiday Rentals' Daily Rates}

Regarding the hedonic valuation of holiday rentals, Pérez-Bastidas and MarmolejoDuarte [38] carried out a pioneer study in which the authors compared two HPMs based on data for the city of Barcelona. The cited research included estimating the price per $\mathrm{m}^{2}$ of housing rentals for residents versus holiday rentals for tourists. The data were obtained from various Web portals such as Apartime, Rent4Days, Apartment Barcelona and Feel Barcelona for holiday rentals and Habitaclia.com for residential rentals. This study highlighted variables such as the availability of air conditioning, as well as the district in which each property was located.

Dogru and Pekin [39], in turn, included variables such as the number of photos on the Web and users' assessments in determining the valuation of Airbnb properties in the city of Boston in the US. Using the same data source and similar variables, Wang and Nicolau [40] developed a model for 33 cities, demonstrating the non-relevance to holiday rentals of variables traditionally important for hotel stays. Gibbs, Guttentag, Morton and Goodwill [41] did the same for various metropolitan areas in Canada, while Önder, Weismayer and Gunter [42] focused on Tallinn in Estonia and Lawani, Reed, Mark and Zheng [43] concentrated on Boston, US. The last two studies introduced variables related to accommodations' size, such as the number of bedrooms [42] and the number of persons an apartment can accommodate [43]. Finally, Tong and Gunter [44] employ the HPM to estimate accommodation prices in Madrid, Barcelona and Seville using Airbnb as the main data source, highlighting the relevance of the number of photos variable, similar to [34].

The analysis of the relevant literature on the topic in question revealed no studies of how holiday rentals' daily rates are estimated that used Booking.com as the primary source of data or any other research using such a comprehensive range of variables to analyse holiday rentals. Therefore, the present study's originality is based on an innovative combination of variables validated by different authors and the use of Booking.com as the key data source. 


\section{Materials and Methods}

This section is divided into three subsections. The first explains the population, sample and variable dataset. The second subsection presents the criteria for selecting variables and data extraction. The last subsection deals with the models' development.

\subsection{Population, Sample and Dataset}

In the Andalusian legislation [45] regulating holiday rentals in Seville, these accommodations are designated as viviendas con fines turísticos (VFTs) (i.e., homes for tourism purposes). The legislation defines VFTs as "those situated in real estate located on land used for residential use, where accommodation services are offered for tourism purposes in exchange for payment of a regular price". This law also states that VFTs can be rented in full (i.e., the entire flat) or in part (i.e., a spare room). In addition, the Andalusian Tourism Law [46] states that different types of tourist accommodations, including VFTs, must be registered with the Registro de Turismo de Andalucía (RTA) (i.e., the Andalusian Tourism Registry).

As can be seen in Figure 3, Seville registered an increase of $296.33 \%$ in the number of VFTs over the period analysed (i.e., January 2017 to March 2019). As the legislation that regulates VFTs (i.e., Decreto 28 2016) entered into force quite recently, no official records are available with which to analyse the growth of this type of accommodation over a longer period.

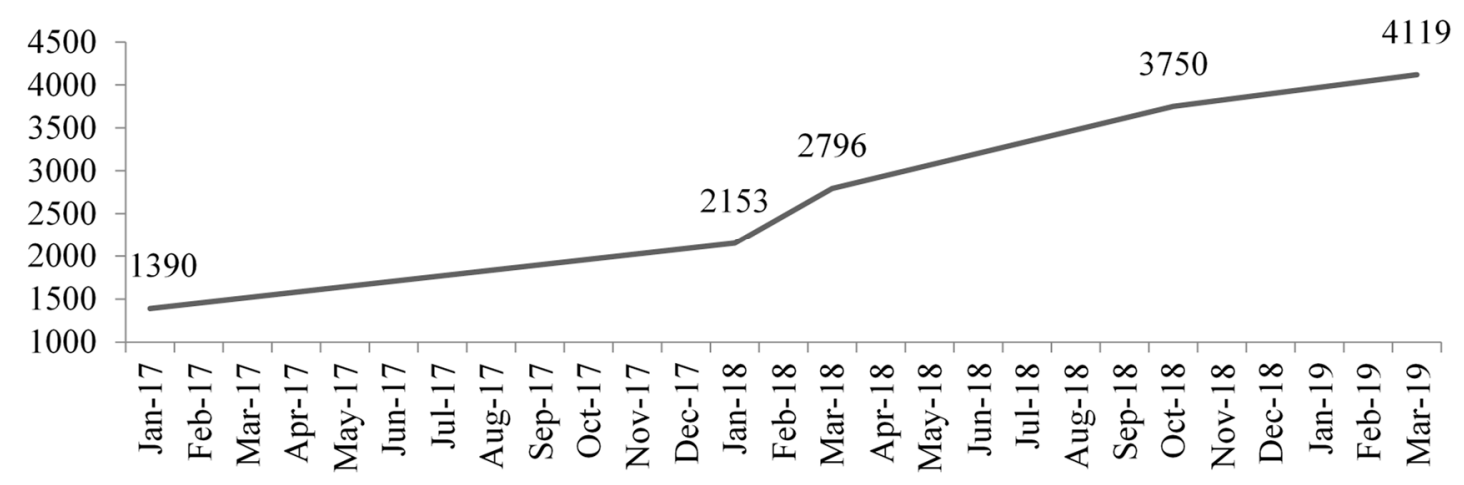

Figure 3. Evolution of number of viviendas con fines turísticos (VFTs) in Seville. Source: RTA [47-49].

As Figure 4 shows, VFTs already carry a similar weight to hotel establishments in relative terms. The rest of the accommodations comprise tourist apartments (TAs) (see Figure 4), which consist of a unique registry of three or more apartments distributed in the same or different buildings. In some cases, TAs include common areas (as in hotel establishments) with a reception, lounge, restaurant and/or swimming pool.

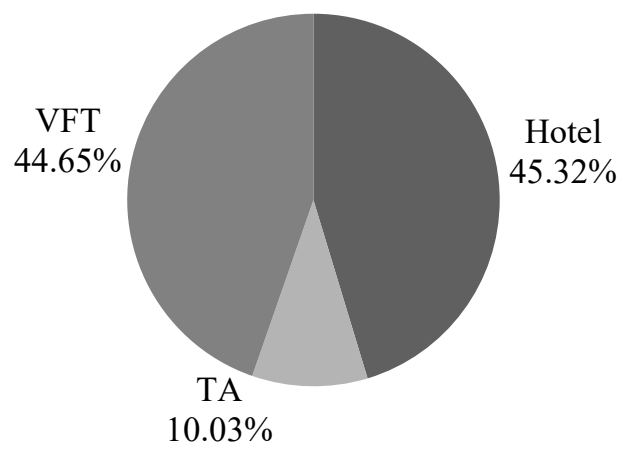

Figure 4. Tourist accommodation beds in Seville (March 2019). Source: RTA [49]. 
Data for the study were based on Solano et al. [50]. All VFTs registered as offering the full modality (i.e., the entire flat) in Seville were taken as a reference point for the total research population. The per room modality was excluded from the sample due to the distortion that could occur in the models if different services were compared. VFTs registered as offering the per room modality were also not considered significant because they account for only $7.5 \%$ of the research population [49]. The total number of VFTs in Seville at the time of data collection (i.e., October 2018) was 3750 (see Figure 3 above), with 3467 offering the full modality, from which a sample of 665 was extracted. The sample considered was the part of the population from which complete data relevant to the elaboration of the intended models could be obtained. Regarding data extraction, the RTA, which is ordered by registration number, was taken and, through a Google search with the following structure: "apartment registration no." + "Booking" + "Seville", the holiday rental profile in Booking.com was found. It was then verified if both the address of the accommodation and the registration number matched in RTA and Booking.com. This was followed by data extraction to a Microsoft Excel file, which was refined and later incorporated into SPSS statistics software. This final sample was selected from a total of 1623 cases because the VFTs included various offers with a different number of beds.

The variables adopted for the sample were based on the evidence found in previous studies analysed in the above literature review; these are listed in Table 1. A descriptive analysis facilitated a fuller understanding of the sample. Thus, holiday rentals in Seville had an average price per day of approximately 162 euros $(€)$ and were about a 15 min walk on average from the Plaza del Triunfo. With regard to size, the accommodations were on average $76 \mathrm{~m}^{2}$ with four beds. Almost all the VFTs had a TV and washing machine, and approximately $40 \%$ of the sample had a balcony, terrace, patio or view. Only a small minority $(3 \%)$ had a swimming pool.

Table 1. Variables, statistics and description.

\begin{tabular}{|c|c|c|c|c|}
\hline Variable & Mean or $\%$ & Std. Deviation & Description & Var. Used \\
\hline PRICE & 162.093 & 105.542 & Accommodation price per day & All HPM models \\
\hline MIN & 14.71 & 8.531 & $\begin{array}{l}\text { Minutes to walk calculated from all the } \\
\text { accommodations considered to the } \\
\text { spot of maximum tourist interest } \\
\text { (i.e., Plaza del Triunfo, Seville) }\end{array}$ & Authors \\
\hline DINDEX & 0.959 & 0.092 & District index according to price per $\mathrm{m}^{2}$ & Authors \\
\hline BEDS & 3.94 & 1.9 & Number of beds & Wang and Nicolau (2017) \\
\hline M2 & 75.8 & 40.818 & $\mathrm{M}^{2}$ & Chen and Rothschild (2010) \\
\hline TV & $99 \%$ & 0.078 & TV $(\mathrm{No}=0 ; \mathrm{Yes}=1)$ & Chen and Rothschild (2010) \\
\hline WASHM & $96 \%$ & 0.2 & Washing machine $(\mathrm{No}=0 ; \mathrm{Yes}=1)$ & $\begin{array}{c}\text { Pérez Bastidas and } \\
\text { Marmolejo Duarte (2014) }\end{array}$ \\
\hline BALCONY & $44 \%$ & 0.497 & Balcony $(\mathrm{No}=0$; Yes $=1)$ & Rigall i Torrent et al. (2011) \\
\hline TERRACE & $36 \%$ & 0.479 & Terrace $(\mathrm{No}=0 ;$ Yes $=1)$ & $\begin{array}{c}\text { Pérez Bastidas and } \\
\text { Marmolejo Duarte (2014) }\end{array}$ \\
\hline CRTYD & $34 \%$ & 0.473 & Courtyard $(\mathrm{No}=0 ;$ Yes $=1)$ & Authors \\
\hline VIEWS & $53 \%$ & 0.499 & Views $(\mathrm{No}=0 ; \mathrm{Yes}=1)$ & Authors \\
\hline SND & $21 \%$ & 0.407 & Soundproofing $(\mathrm{No}=0 ;$ Yes $=1)$ & Stojchevska et al. (2018) \\
\hline PARK & $40 \%$ & 0.491 & Parking $(\mathrm{No}=0 ; \mathrm{Yes}=1)$ & Coenders et al. (2003) \\
\hline PETS & $11 \%$ & 0.319 & Pets permitted $(\mathrm{No}=0 ; \mathrm{Yes}=1)$ & Kuminoff et al. (2010) \\
\hline POOL & $3 \%$ & 0.157 & Pool $(\mathrm{No}=0 ;$ Yes = 1) & Andersson (2010) \\
\hline BATH & $34 \%$ & 0.474 & Bathtub $(\mathrm{No}=0$; Yes = 1) & Chen and Rothschild (2010) \\
\hline
\end{tabular}


Table 1. Cont.

\begin{tabular}{ccccc}
\hline Variable & Mean or $\%$ & Std. Deviation & Description & Var. Used \\
\hline CAL & 8.872 & 0.678 & Evaluation of previous users (from 0 to 10) & Wang and Nicolau (2017) \\
\hline PICS & 32.8 & 11.22 & Number of photos & Dogru and Pekin (2017) \\
\hline VSAP & 8.403 & 0.826 & $\begin{array}{c}\text { Visual appeal according to photos } \\
\text { (from 0 to 10) }\end{array}$ & Authors \\
\hline HSWD & $35 \%$ & 0.477 & High season, weekday (No = 0; Yes =1) & Authors \\
\hline HSWE & $13 \%$ & 0.341 & High season, weekend (No = 0; Yes =1) & Authors \\
\hline LSWD & $29 \%$ & 0.452 & Low season, weekday (No = 0; Yes = 1) & Authors \\
\hline LSWE & $10 \%$ & 0.304 & Low season, weekend (No = 0; Yes =1) & Authors \\
\hline SE1 & $8 \%$ & 0.271 & $\begin{array}{c}\text { Special event 1 (Holy Week in Seville) } \\
\text { (No = 0; Yes = 1) }\end{array}$ & Authors \\
SE2 & $5 \%$ & 0.215 & $\begin{array}{c}\text { Special event 2 (April Fair in Seville) } \\
\text { (No = 0; Yes = 1) }\end{array}$ & $\begin{array}{c}\text { Soler García and Gémar } \\
\text { Castillo (2017) }\end{array}$ \\
\hline
\end{tabular}

Note: Std. = standard; var. $=$ variable

\subsection{Variables}

The information obtained was extracted from Booking.com [51]. The exceptions were the minutes needed to walk from accommodations to the spot of maximum tourist interest (MIN) (see Table 1 above), which was calculated based on Google Maps [52] and district index (DINDEX), which was taken from Tinsa [53]. The VSAP variable's score was estimated based on an evaluation carried out for the present study.

The price (PRICE) was extracted per accommodation and day for a two-day stay, which is the average stay in Seville according to the Centro de Datos Turísticos del Ayuntamiento de Sevilla [54] (i.e., the Tourism Data Centre of Seville). This variable includes taxes and other added expenses (e.g., cleaning, when paid separately). During the data collection process, whenever a property offered different types of apartments at the same price, the one that offered the highest added value was chosen to reflect a rational consumer's behaviour. Finally, the option for cancellation in a specific period and/or a partial refund was given priority. The non-refundable option was selected only when no other option was available.

Regarding the minutes needed to walk from accommodations to the spot of maximum tourist interest (MIN), Plaza del Triunfo was chosen for Seville because this square is located between the Cathedral of Seville and the Real Alcázar. These are the two most visited monuments according to the Centro de Datos Turísticos del Ayuntamiento de Sevilla [54]. The present study hypothesised that this variable could affect prices negatively, since the shorter the time spent on reaching the spot of maximum interest, the more expensive the accommodations should become.

The district index (DINDEX) was constructed from the average price per $\mathrm{m}^{2}$ of housing in Seville, according to the district in which the accommodations were located. The district with the highest price took the value of one, and the rest of the districts took a proportional value, as shown in Table 2. This research hypothesised that a higher value per $\mathrm{m}^{2}$ in the district implies a higher value of the property, which will be passed on to customers.

Additional tests were carried out on the models, taking each district as a "dummy" variable except for one, which served as the reference point. The inclusion of all the districts at once would have created a problem of exact multicollinearity in the models.

The accommodations' size was reflected in the sample through two variables: the surface of the property measured in $\mathrm{m}^{2}$ (M2) and the number of beds offered (BEDS). This approach was based on the hypothesis that a larger-sized property implies a higher value, which will again be passed on to guests. Similarly, an offer that involves a higher number of beds implies a more significant expenditure on such things as electricity, water and cleaning, so this variable should positively influence prices. 
Table 2. District index (DINDEX).

\begin{tabular}{ccc}
\hline District & $\mathbf{\epsilon} / \mathbf{m}^{\mathbf{2}}$ & Index \\
\hline Casco Antiguo (Old Town) & 2398 & 1 \\
Los Remedios & 2196 & 0.916 \\
Nervión & 2137 & 0.891 \\
Triana & 1932 & 0.806 \\
Sur & 1825 & 0.761 \\
San Pablo-Santa Justa & 1629 & 0.679 \\
Bellavista-La Palmera & 1578 & 0.658 \\
Macarena & 1301 & 0.543 \\
Este-Alcosa-Torreblanca & 1226 & 0.511 \\
Norte & 1041 & 0.434 \\
Cerro Amate & 974 & 0.406 \\
\hline
\end{tabular}

Source: Tinsa [53].

The selection of the variables related to amenities and other accommodation features was carried out through a search on Booking.com [51] regarding holiday rentals and tourist apartments (see Table 3). The selection criterion discriminated between the most frequently present variables (e.g., WiFi and air conditioning) and the least common ones (e.g., a gym or spa), which were not considered in the models. The latter type of variables often has little impact on prices, so these amenities are not especially significant in price composition. Furthermore, less common variables can generate atypical cases that cause distortions in the models. The variables were thus selected from the remaining frequently offered amenities.

Table 3. Amenities for holiday rentals and tourist apartments in Seville.

\begin{tabular}{ccc}
\hline $\begin{array}{c}\text { Equipment (Availability of } \\
\text { Goods or Services) }\end{array}$ & No. of Accommodations & \% of Accommodations \\
\hline Free WiFi connection & 917 & $96.53 \%$ \\
Air conditioner & 914 & $96.21 \%$ \\
Washing machine & 836 & $88.00 \%$ \\
TV & 827 & $87.05 \%$ \\
Balcony & 445 & $46.84 \%$ \\
Parking & 385 & $40.53 \%$ \\
View & 362 & $38.11 \%$ \\
Terrace & 355 & $37.37 \%$ \\
Courtyard & 342 & $36.00 \%$ \\
Soundproofing & 208 & $21.89 \%$ \\
Bath & 199 & $20.95 \%$ \\
Pets allowed & 106 & $11.16 \%$ \\
Swimming pool & 24 & $2.53 \%$ \\
Restaurant & 16 & $1.68 \%$ \\
Fitness centre & 10 & $1.05 \%$ \\
Room service & 9 & $0.95 \%$ \\
Electric vehicle charging station & 7 & $0.74 \%$ \\
Spa and wellness centre & 5 & $0.53 \%$ \\
TOTAL & 950 & $100.00 \%$ \\
\hline
\end{tabular}

Note: No. = number. Source: Booking.com [51].

Regarding the view variable, only views including the city and/or emblematic monuments were included, thereby excluding views of courtyards and/or interior gardens. Concerning the availability of parking, both the establishments' facilities and the presence of private parking in the surrounding area were considered.

Finally, the price was taken from various periods. Six intervals were considered (see Table 1 above). The first four were high season, weekday (HSWD, price from 27 to 29 May 2019); high season, weekend (HSWE, price from 31 May 2019 to 2 June 2019); low season, weekday (LSWD, price from 14 to 16 January 2019); low season, weekend (LSWE, price from 18 to 20 January 2019). The last two price variables were from Holy Week, 
which is a special event in the city (SE1, price from 18 to 20 April 2019) and the April Fair, also an important event in Seville (SE2, price from 10 to 12 May 2019).

To estimate the seasonality variables' weighting, the sample was divided into approximately two equal parts (see Table 1 above) based on high and low seasons: high season was from April to September and low season was from October to March. A more significant weight was given to the high season due to the higher occupation rate during this period. A similar approach was used regarding weekends, as they represent more than two-sevenths of cases compared to weekdays, because of the marked increase in overnight stays on weekends. Given the much higher occupancy rate during Holy Week, the $2 \%$ that this week represents out of the total days of the year was quadrupled in weight. The same approach was used for the April Fair as the city's second special event, so the weighting of the days involved was approximately double the normal $2 \%$ for this period.

\subsection{Models Development}

With the 1623 cases in the sample, two models were constructed using the HPM method and software programmes such as IBM SPSS Statistics version 25 and EViews version 10. Models that use the HPM can acquire various functional forms. In the estimation of these particular models, the double logarithmic function (Equation (1)) and linear function (Equation (2)) were taken as a reference point. Logarithmic coefficients obtained present the elasticities of these relevant variables regarding the price, and linear coefficients reflect direct marginal influences on it. Thus, after conducting different tests with other forms, these functions were shown to be the ones that performed better. In double logarithmic functions, dummy variables remain without logarithmic transformation, presenting its coefficients only an additive effect. In addition, these types of functions are commonly used in HPM models similar to the proposed.

$$
\begin{gathered}
\operatorname{Ln}(Y)=\beta_{0}+\beta_{1} \ln \left(X_{1}\right)+\beta_{2} \ln \left(X_{2}\right)+\beta_{3} \ln \left(X_{3}\right)+\ldots+\beta_{n} \ln \left(X_{n}\right)+\varepsilon \\
Y=\beta_{0}+\beta_{1} X_{1}+\beta_{2} X_{2}+\beta_{3} X_{3}+\ldots+\beta_{n} X_{n}+\varepsilon
\end{gathered}
$$

\section{Results}

After different variable combination tests, the following non-significant independent variables were excluded: DINDEX, TV, WASHM, BALCONY, TERRACE, CRTYD, VIEWS, SND, PARK, PETS, BATH, CAL and PICS. The logarithmic model's remaining significant variables are shown in Table 4 . The same relevant variables were obtained in the linear model (Table 5). By including some additional non-significant variables, the Akaike and Bayesian information criterion measures worsened, so this combination of variables was chosen. In all of them, the probability (prob.) of error if the null hypothesis was rejected using the Student's t-statistic was less than $1 \%$ (prob. $<0.01$ ); excluding POOL, it was less than $0.1 \%$. Two atypical cases considered as non-representative were also excluded from the models because their inclusion significantly distorted them. The variables referring to location (MIN), property size (M2 and BEDS), amenities (POOL) and seasonality (HSWE, LSWD, LSWE, SE1 and SE2) were validated as important to daily price composition.

The first observation that could be made based on these results (see Tables 4 and 5 above) was that, in the case of variables related to seasonality, HSWD functioned as a base value; thus, this variable was excluded from the models as its inclusion would present a multicollinearity problem. Additional tests to eliminate multicollinearity between independent variables were performed using the VIF (see Tables 4 and 5 above). No independent variables exceeded the multicollinearity tolerance cut-off point, which was established as 10 . 
Table 4. Variables of logarithmic model using the hedonic pricing method (HPM).

\begin{tabular}{cccccc}
\hline Variable & Coefficient & Standard Error & Student's T & Prob. & VIF \\
\hline Constant (C) & 1.912 & 0.16 & 1.197 & 0.000 & - \\
Ln(MIN) & -0.115 & 0.0106 & -1.092 & 0.000 & 1.098 \\
Ln(M2) & 0.288 & 0.0161 & 1.786 & 0.000 & 1.409 \\
Ln(BEDS) & 0.328 & 0.016 & 2.101 & 0.000 & 1.31 \\
POOL & 0.114 & 0.042 & 2.707 & 0.007 & 1.039 \\
Ln(VSAP) & 0.788 & 0.073 & 1.075 & 0.000 & 1.249 \\
HSWE & 0.088 & 0.021 & 4.179 & 0.000 & 1.205 \\
LSWD & -0.254 & 0.016 & -1.546 & 0.000 & 1.317 \\
LSWE & -0.16 & 0.023 & -6.92 & 0.000 & 1.172 \\
SE1 (Holy Week) & 0.768 & 0.026 & 2.997 & 0.000 & 1.145 \\
SE2 (April Fair) & 0.618 & 0.031 & 1.966 & 0.000 & 1.09 \\
\hline
\end{tabular}

Note: Prob. = probability; VIF = variance inflation factor.

Table 5. Variables of linear model using HPM.

\begin{tabular}{cccccc}
\hline Variable & Coefficient & Standard Error & Student's T & Prob. & VIF \\
\hline Constant (C) & -65.15 & 15.198 & -4.287 & 0.000 & - \\
MIN & -1.475 & 0.159 & -9.262 & 0.000 & 1.104 \\
M2 & 0.935 & 0.041 & 23.055 & 0.000 & 1.64 \\
BEDS & 14.827 & 0.835 & 17.75 & 0.000 & 1.509 \\
POOL & 31.021 & 8.437 & 3.677 & 0.000 & 1.05 \\
VSAP & 12.88 & 1.765 & 7.296 & 0.000 & 1.27 \\
HSWE & 17.395 & 4.167 & 4.175 & 0.000 & 1.21 \\
LSWD & -30.784 & 3.285 & -9.372 & 0.000 & 1.321 \\
LSWE & -24.09 & 4.601 & -5.236 & 0.000 & 1.171 \\
SE1 (Holy Week) & 151.866 & 5.116 & 29.686 & 0.000 & 1.147 \\
SE2 (April Fair) & 130.659 & 6.27 & 20.84 & 0.000 & 1.091 \\
\hline
\end{tabular}

Note: Prob. = probability; VIF = variance inflation factor.

Elasticities of prices against several exogenous variables were deducted directly from the model coefficients (Table 4). For example, price elasticity with respect to size was 0.288 , congruent with the law of diminishing returns since an additional $\mathrm{m}^{2}$ tends to be valued less and less. Additionally, the MIN variable presented a negative effect, as every extra minute spent walking from the spot of maximum tourist interest (i.e., Plaza del Triunfo) to the accommodation had a decreasing effect on its price. The same outcome could also be seen in low season variables (LSWD and LSWE). The coefficients in linear equation (Table 5) represent the marginal variations that occur in prices (i.e., endogenous variable) for each exogenous variable. For example, every extra minute needed to walk from accommodations to the spot of maximum tourist interest reduced the daily rate by $€ 1.48$. Similarly, the availability of a pool in the VFTs increased the price per day by $€ 31.02$.

Regarding residual analysis, Figure 5 presents a graph comparing a predicted price versus residuals graph, which does not show trends in variability along with the price range. Additionally, an alternative estimation procedure used White-Hinckley heteroskedasticity consistent standard errors for obtaining the t-statistics associated with the model's coefficients, but the final results were quite similar, as there were no signs of heteroskedasticity.

Table 6 shows the assessment of the models' adjustment. The most significant result was a coefficient of determination $\left(R^{2}\right)$ similar in both models. This means that the set of exogenous variables explained around $73 \%$ of the endogenous variable in the two HPM models proposed. The mean absolute percentage error (MAPE) revealed the differences, expressed in percentage, detected between the prices predicted by the models and their real values. In the logarithmic case, a relatively low MAPE was presented when the model estimated the logarithmic transformation of the price. However, the predicted prices were similar when comparing both models, reflecting values around $20 \%$ above or below the real value. Regarding the Bayesian information criterion (BIC), the logarithmic model presented 
a significantly lower value than the linear model and consequently a better adjustment than the latter. Finally, the proximities to zero of the Theil inequality indexes in both cases revealed the models' high predictive capacity.

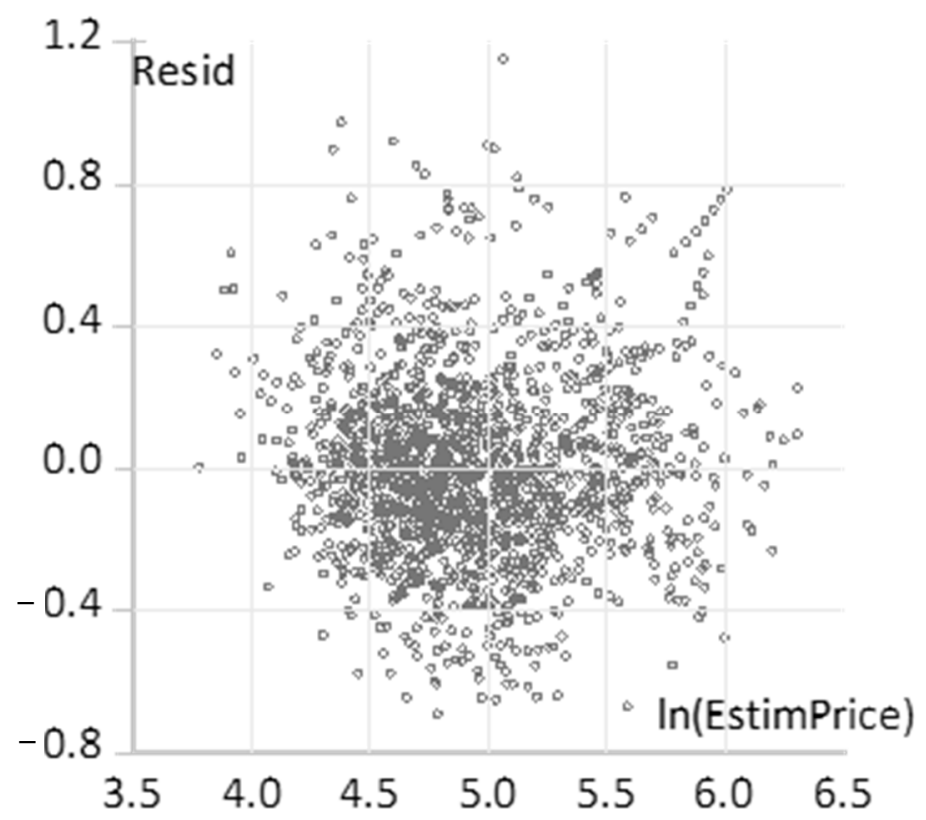

Figure 5. Predicted price vs. residuals.

Table 6. Measures of adjustment of logarithmic and linear models using HPM.

\begin{tabular}{ccc}
\hline Test & Logarithmic & Linear \\
\hline$R^{2}$ & 0.731 & 0.732 \\
MAPE & Ln(PRICE) $=3.96 \%$ PRICE $=19.62 \%$ & $22.94 \%$ \\
BIC & 0.193 & 10.79 \\
Theil inequality index & 0.026 & 0.139 \\
\hline
\end{tabular}

Note: $R^{2}$ = coefficient of determination; MAPE = mean absolute percentage error; BIC = Bayesian information criterion.

\section{Discussion}

The exogenous variables were thus classified as important in the models, which is in line with previous studies examined in the literature review. These include, for instance, Espinet et al. [25] and Soler-García and Gémar-Castillo's [32] findings for distance to the city centre. However, in the present study, the distance is measured in time spent walking from the accommodation (as it is easily recognisable for users) to the most interesting spot; this is different than in [25], in which distance is determined through a dummy variable, and [32], which uses length measurement. Similar results were reported by Chen and Rothschild [27] in relation to size in $\mathrm{m}^{2}$. Size of the property is also recurrent in the literature regarding real estate valuation $[19,20]$.

Concerning amenities, only the inclusion of pool availability was considered along the lines of Kuminoff et al. [30] and Sánchez Ollero et al. [31]. This research focused on the willingness of an extra payment for "green" or "environmentally friendly" hotels. Nevertheless, reasons for users' pool appreciation may be different as Seville is one of the hottest places in Europe, especially during summer. Seasonality also plays an important role in this work, in line with Coenders et al. [24] and Rigall i Torrent et al. [26]. However, these studies are linked with sun-and-beach tourism, unlike the present research, which focuses on cultural tourism. While high and low season periods differ in dissimilar types of tourism, they are determinant in both this study and in [24,26]. Special events in the city also have an impact on daily rates, as is seen in [32]. 
However, the previously established hypothesis about the district index was rejected in the current research. The average real estate price per $\mathrm{m}^{2}$ in the districts in which the accommodations were located did not have a decisive impact on daily rates in Seville, as more than $80 \%$ of the dataset cases were concentrated in "Casco Antiguo" (the old town district) (see [50]). Other independent variables such as views, courtyard and number of photos, which were relevant in [44], also proved to be irrelevant in the present research. Most of the variables related to amenities were insufficiently influential in daily price composition. These include TV (determinant in [27]), washing machine (which presented the same non-relevance as in [38]), balcony (relevant in [26]), soundproofing (showing incidence in [35]), parking (whose importance was highlighted in [24]), pet admission (presenting high relevance in [30]) and bathtub (presenting as relevant in [27]).

\section{Conclusions and Implications}

The present study's main aim, as stated in Section 1, was to develop a hedonic regression model capable of estimating the daily prices of stays in holiday rentals. The HPM models developed present adequate functional forms (i.e., logarithmic and linear) with independent variables that are sufficiently significant and that do not show any apparent multicollinearity among themselves. Using predetermined variables, the models were tested, and the results confirm the accuracy in terms of determining holiday rentals' daily rates in a cultural city tourism destination with a large number of this type of accommodation.

The research's additional objectives were to test the effect of the variables included in the dataset on the estimation of holiday rentals' daily price and to exclude any non-relevant variables. Regarding the models' independent variables, previously confirmed research hypotheses have referred to factors such as location (measured as minutes walked from accommodations to the spot of maximum tourist interest) and size (measured in $\mathrm{m}^{2}$ and number of beds), which were also validated by the present study. The proposed models further assign a primary role to amenities (i.e., pool availability), appearance (i.e., visual appeal) and seasonality (i.e., high and low seasons, with their respective subdivisions into weekdays and weekends, as well as the special events of Holy Week and April Fair). These variables decisively influence daily rates.

\subsection{Theoretical Implications}

This research is innovative in several aspects. First, using Booking.com as the main data source for holiday rentals' valuation allows the inclusion of variables such as the property's size or those related to its exact location. Previous research has mainly used Airbnb or TripAdvisor listings, in which the variables mentioned above are lacking in most of cases. Second, the distance to the spot of maximum tourist interest is measured in minutes spent walking, adding a more comprehensive criterion from the point of view of the users, and excluding taking distance to the centre as a dummy variable or measuring it in length, as in previous research [25,32]. Thus, this study reveals a strong influence in holiday rentals' daily rates by the size and the minutes spent walking from the accommodation to the point of interest.

\subsection{Practical Implications}

These models can help owners of holiday rentals to fix their daily rates more accurately based on the properties' conditions (i.e., $\mathrm{m}^{2}$, beds offered or amenities available) or the period during which the accommodations are offered. For potential clients, these models provide guidelines for assessing if daily rates available on the Internet are under- or overvalued compared to what the market would normally offer under the same circumstances. Finally, although this study uses data from Seville, the main findings in terms of pricing and relevance of the variables could be extrapolated to similar places, especially medium and large cultural European cities with a concentrated old town. 


\subsection{Limitations and Recommendations}

The proposed models' degree of adjustment obtained suggests that a margin for improvement exists. Factors such as this type of accommodations' considerable heterogeneity made more precise estimations difficult to achieve, considering the inclusion of additional variables. There has been a slight limitation regarding data extraction, as [49] include some incomplete data registries, and a few accommodations are not available on the dates selected in Booking.com, especially during special events such as the Holy Week and April Fair. Further validation of the proposed models could include replicating the methodology of this study using data from other cultural city destinations such as Madrid, Barcelona, Paris, Rome, Venice, Oporto or Amsterdam.

Author Contributions: Conceptualization, J.A.C.S. and M.Á.S.-S.; methodology, J.A.C.S., M.Á.S.S., F.J.R.-C. and L.C.y.L.d.R.; software, M.A.F.-G. and M.Á.S.-S.; validation, J.A.C.S., M.A.F.-G., F.J.R.-C. and L.C.y.L.d.R.; formal analysis, J.A.C.S., M.A.F.-G., M.Á.S.-S., F.J.R.-C. and L.C.y.L.d.R.; investigation, M.Á.S.-S.; resources, M.Á.S.-S.; writing—review and editing, J.A.C.S., M.Á.S.-S., F.J.R.C. and L.C.y.L.d.R.; supervision, F.J.R.-C. and L.C.y.L.d.R.; funding acquisition, J.A.C.S. All authors have read and agreed to the published version of the manuscript.

Funding: This paper is financed by FCT—Foundation for Science and Technology through project UIDB/04020/2020.

Institutional Review Board Statement: Not applicable.

Informed Consent Statement: Not applicable.

Data Availability Statement: The authors confirm that this research is original, free of plagiarism and adheres to COPE's Code of Conduct and Best Practice Guidelines.

Conflicts of Interest: All authors declare no conflict of interest in this paper.

\section{References}

1. Guttentag, D. Airbnb: Disruptive innovation and the rise of an informal tourism accommodation sector. Curr. Issues Tour. 2015, 18, 1192-1217. [CrossRef]

2. Veiga, C.; Santos, M.C.; Águas, P.; Santos, J.A.C. Sustainability as a key driver to address changes. World. Hosp. Tour. Themes 2018, 10, 662-673. [CrossRef]

3. Lu, L.; Tabari, S. Impact of Airbnb on customers' behavior in the UK hotel industry. Tour. Anal. 2019, 24, 13-26. [CrossRef]

4. Heo, C.Y.; Blal, I.; Choi, M. What is happening in Paris? Airbnb, hotels, and the Parisian market: A case study. Tour. Manag. 2019, 70, 78-88. [CrossRef]

5. Wegmann, J.; Jiao, J. Taming Airbnb: Toward guiding principles for local regulation of urban vacation rentals based on empirical results from five US cities. Land Use Policy 2017, 69, 494-501. [CrossRef]

6. Gwin, C.R. International comparisons of real estate e-information on the internet. J. Real Estate Res. 2004, 26, 1-24. [CrossRef]

7. Parolin, C.F.; Boeing, R. Consumption of boutique hotel experiences as revealed by electronic word-of-mouth. Tour. Manag. Stud. 2019, 15, 33-45. [CrossRef]

8. Castro, C.; Ferreira, F.A. Online hotel ratings and its influence on hotel room rates: The case of Lisbon, Portugal. Tour. Manag. Stud. 2018, 14, 63-72. [CrossRef]

9. Perez-Aranda, J.; Vallespín, M.; Molinillo, S. A proposal for measuring hotels' managerial responses to User-Generated-Content Reviews. Tour. Manag. Stud. 2018, 14, 7-16. [CrossRef]

10. Pinto, I.; Castro, C. Online travel agencies: Factors influencing tourists' purchase decisions. Tour. Manag. Stud. 2019, 15, 7-20. [CrossRef]

11. Rodríguez-Díaz, M.; Rodríguez-Díaz, R.; Rodríguez-Voltes, A.C.; Rodríguez-Voltes, C.I. Analysing the relationship between price and online reputation by lodging category. Sustainability 2018, 10, 4474. [CrossRef]

12. Santos, M.C.; Ferreira, A.; Costa, C.; Santos, J.A.C. A Model for the development of innovative tourism products: From service to transformation. Sustainability 2020, 12, 4362. [CrossRef]

13. Statista. Vacation Rentals Worldwide. 2019. Available online: https://www.statista.com/outlook/268/100/vacation-rentals/ worldwide? currency=usd\#market-revenue (accessed on 15 February 2020).

14. Court, A.T. Hedonic price indexes with automotive examples. In General Motors Corporation, the Dynamics of Automobile Demand; General Motors Corporation: Detroit, MI, USA, 1939; pp. 99-117.

15. Rosen, S. Hedonic prices and implicit markets: Product differentiation in pure competition. J. Polit. Econ. 1984, 82, 34-55. [CrossRef]

16. Ridker, R.G.; Henning, J.A. The determinants of residential property values with special reference to air pollution. Rev. Econ. Stat. 1967, 49, 246-257. [CrossRef] 
17. Kang, H.-B.; Reichert, A.K. An empirical analysis of hedonic regression and grid-adjustment techniques in real estate appraisal. Real Estate Econ. 1991, 19, 70-91. [CrossRef]

18. Palmquist, R.B. Alternative techniques for developing real estate price indexes. Rev. Econ. Stat. 1980, 62, 442-448. [CrossRef]

19. Brañas-Garza, P.; Caridad y Ocerin, J.M. Demanda de características de la vivienda en Córdoba: Un modelo de precios hedónico. Rev. Est. Reg. 1996, 46, 139-153.

20. Ceular-Villamandos, N.; Caridad y Ocerin, J.M. Un análisis del mercado de la vivienda a través de redes neuronales artificiales. Estud. Econ. Aplic. 2001, 18, 67-81.

21. Muñoz Fernández, G.A. Análisis de la Vivienda en Córdoba. Estudio Econométrico. Ph.D. Thesis, University of Cordoba, Cordoba, Spain, 2012.

22. Núñez Tabales, J.M.; Rey Carmona, F.; Caridad y Ocerin, J.M. Artificial Intelligence (AI) techniques to analyze the determinants attributes in housing prices. Intelig. Artif. 2016, 19, 23-38. [CrossRef]

23. Núñez Tabales, J.M.; Rey Carmona, F.; Caridad y Ocerin, J.M. Commercial properties prices appraisal: Alternative approach based on neural networks. Int. J. Artif. Intell. 2016, 14, 53-70.

24. Coenders, G.; Espinet, J.; Sáez, M. Predicting random level and seasonality of hotel prices: A latent growth curve approach. Tour. Anal. 2003, 8, 15-31. [CrossRef]

25. Espinet, J.M.; Sáez, M.; Coenders, G. Effect on prices of the attributes of holiday hotels: A hedonic prices approach. Tour. Econ. 2003, 9, 165-177. [CrossRef]

26. Rigall, I.; Torrent, R.; Fluvià, M.; Ballester, R.; Saló, A.; Ariza, E.; Espinet, J.M. The effects of beach characteristics and location with respect to hotel prices. Tour. Manag. 2011, 32, 1150-1158. [CrossRef]

27. Chen, C.-F.; Rothschild, R. An application of hedonic pricing analysis to the case of hotel rooms in Taipei. Tour. Econ. 2010, 16, 685-694. [CrossRef]

28. Andersson, D.E. Hotel attributes and hedonic prices: An analysis of internet-based transactions in Singapore's market for hotel rooms. Ann. Reg. Sci. 2010, 44, 229-240. [CrossRef]

29. Zhang, Z.; Ye, Q.; Law, R. Determinants of hotel room price: An exploration of travelers' hierarchy of accommodation needs. Int. J. Contemp. Hosp. Manag. 2011, 23, 972-981. [CrossRef]

30. Kuminoff, N.V.; Zhang, C.; Rudi, J. Are travelers willing to pay a premium to stay at a "green" hotel? Evidence from an internal meta-analysis of hedonic price premia. Agric. Resour. Econ. Rev. 2010, 39, 468-484. [CrossRef]

31. Sánchez-Ollero, J.L.; García-Pozo, A.; Marchante-Mera, A. How does respect for the environment affect final prices in the hospitality sector? A hedonic pricing approach. Cornell Hosp. Q. 2014, 55, 31-39. [CrossRef]

32. Soler-García, I.P.; Gémar-Castillo, G. Impact of the April Fair on Seville hotel room prices: Measurement through a hedonic approach. Tour. Manag. Stud. 2017, 13, 7-12. [CrossRef]

33. Soler-García, I.P.; Gémar-Castillo, G. Hedonic price models with geographically weighted regression: An application to hospitality. J. Dest. Mark. Manag. 2018, 9, 126-137. [CrossRef]

34. Soler García, I.P.; Gémar Castillo, G.; Correia, M.B.; Serra, F. Algarve hotel price determinants: A hedonic pricing model. Tour. Manag. 2019, 70, 311-321. [CrossRef]

35. Stojchevska, M.; Naumoski, A.; Mitreski, K. Modelling the impact of the hotel facilities on online hotel review score for city of Skopje. In Proceedings of the 2nd International Symposium on Multidisciplinary Studies and Innovative Technologies (ISMSIT), Ankara, Turkey, 19-21 October 2018; pp. 1-5. [CrossRef]

36. Mondaca-Marino, C.; Guala, C.; Montecinos-Astorga, A.L.; Salazar-Concha, C. Factores que influyen en el precio de hoteles en Booking.com. El caso de Santiago de Chile. Inf. Technol. 2019, 30, 87-96. [CrossRef]

37. Nieto-García, M.; Resce, G.; Ishizaka, A.; Occhiocupo, N.; Viglia, G. The dimensions of hotel customer ratings that boost RevPAR. Int. J. Hosp. Manag. 2019, 77, 583-592. [CrossRef]

38. Pérez Bastidas, V.B.; Marmolejo Duarte, C. El impacto de las externalidades producidas por el turismo sobre los valores inmobiliarios y la segmentación del mercado residencial en Barcelona. Archit. City Environ. 2014, 9, 159-188. [CrossRef]

39. Dogru, T.; Pekin, O. What do guests value most in Airbnb accommodations? An application of the hedonic pricing approach. Boston Hosp. Rev. 2017, 5, 1-13.

40. Wang, D.; Nicolau, J.L. Price determinants of sharing economy based accommodation rental: A study of listings from 33 cities on Airbnb.com. Int. J. Hosp. Manag. 2017, 62, 120-131. [CrossRef]

41. Gibbs, C.; Guttentag, D.G.; Morton, J.; Goodwill, A. Pricing in the sharing economy: A hedonic pricing model applied to Airbnb listings. J. Travel Tour. Mark. 2018, 35, 46-56. [CrossRef]

42. Önder, I.; Weismayer, C.; Gunter, U. Spatial price dependencies between the traditional accommodation sector and the sharing economy. Tour. Econ. 2018, 25, 1150-1166. [CrossRef]

43. Lawani, A.; Reed, M.M.; Mark, T.; Zheng, Y. Reviews and price on online platforms: Evidence from sentiment analysis of Airbnb reviews in Boston. Reg. Sci. Urban Econ. 2019, 75, 22-34. [CrossRef]

44. Tong, B.; Gunter, U. Hedonic pricing and the sharing economy: How profile characteristics affect Airbnb accommodation prices in Barcelona, Madrid, and Seville. Curr. Issues Tour. 2020, 1-20. [CrossRef]

45. Decreto 28/2016, de 2 de Febrero, de Las Viviendas con Fines Turísticos y de Modificación del Decreto 194/2010, de 20 de Abril, de Establecimientos de Apartamentos Turísticos; Boletín Oficial de la Junta de Andalucía: Seville, Spain, 2016; pp. 66-74.

46. Ley 13/2011, de 23 de Diciembre, del Turismo de Andalucía; Boletín Oficial de la Junta de Andalucía: Seville, Spain, 2011 ; pp. 3-22. 
47. RTA. Oferta de Establecimientos de Alojamiento Turístico. 2016. Available online: http://www.juntadeandalucia.es/ turismoydeporte/publicaciones/estadisticas/rta_2016_v2.pdf (accessed on 15 February 2020).

48. RTA. Oferta de Establecimientos de Alojamiento Turístico. 2017. Available online: http://www.juntadeandalucia.es/ turismoydeporte/publicaciones/estadisticas/rta_2017_v1.pdf (accessed on 15 February 2020).

49. RTA (Registro de Turismo de Andalucía). AT, VFT y VTAR; Consejería de Turismo y Deporte: Sevilla, Spain, 2019.

50. Sánchez, M.A.S.; Tabales, J.M.N.; y Ocerin, J.M.C.; Santos, J.A.C.; Santos, M.C. Dataset for holiday rentals' daily rate pricing in a cultural tourism destination. Data Brief 2019, 27, 104697. [CrossRef] [PubMed]

51. Booking.com. Sevilla, Apartamentos + Casas. Available online: https://www.booking.com/searchresults.es.html?label=gen1 73nr-1FCAEoggI46AdIM1gEaEaIAQGYAQq4ARjIAQzYAQHoAQH4AQuIAgGoAgQ\&sid=15def371e8a93ef38e3a7eada5b1 4ac4\&ac_click_type=b\&ac_position=0\&checkin_month=5\&checkin_monthday=27\&checkin_year=2019\&checkout_month= (accessed on 24 September 2018).

52. Google Maps. Sevilla. Available online: Google.es/maps: https://www.google.es/maps/place/Sevilla/@37.3846082,-5.9944208,15z/ data $=$ !4m5!3m4!1s0xd126c1114be6291:0x34f018621cfe5648!8m2!3d37.3890924!4d-5.9844589?hl=es (accessed on 24 September 2018).

53. Tinsa. Tinsa IMIE Mercados Locales. Informe $2^{\circ}$ Trimestre de 2018. Available online: https://www.tinsa.es/download/307600/ (accessed on 24 September 2018).

54. Centro de Datos Turísticos del Ayuntamiento de Sevilla. Informe Anual 2017; Centro de Datos Turísticos del Ayuntamiento de Sevilla: Sevilla, Spain, 2017. 